ЄЛІЗАРЕНКО А.О., к.т.н., доцент (Український державний університет залізничного транспорту)

ЄЛІЗАРЕНКО І. О., провідний інженер (Харківська філія Українського державного центру радіочастот)

\title{
Особливості впровадження сучасних цифрових радіотехнологій на мережах зв'язку залізниць
}

Проведено порівняльний аналіз цифрових радіотехнологій DMR, GSM-R та LTE-R. Розглянуто принциии побудови та основні техніко - експлуатаційні характеристики радіозасобів та напрямки використання для технологічних абонентів залізничного транспорту. Розроблено рекомендачії з впровадження радіозасобів DMR, GSM-R та LTE-R на мережах рухомого радіозв'язку залізниць.

Проведені розрахунки показали зменшення дальності радіозв'язку в мережах GSM-R ma LTE-R, щзо призводить до збільшення необхідної кількості базових станцій та зростання вартості інфраструктури мереж.

Ключові слова: залізничний технологічний радіозв'язок, изифрові радіотехнологї DMR, GSM-R ma LTE-R, принциии побудови, рекомендації із застосування, розрахунок зон обслуговування радіомереж.

\section{Встуі}

Застосування технологічного радіозв'язку на залізничному транспорті почалося в 1947 р. Сьогодні радіозв'язок широко застосовується у всіх технологічних ланках роботи залізничного транспорту. Для різних категорій абонентів організовуються окремі радіомережі. Періодично проводилися роботи 3 модернізації радіозасобів i вдосконалення мереж радіозв'язку. Остання системна модернізація проводилася на початку $80-\mathrm{x}$ років при розробці комплексної уніфікованої системи технологічного радіозв'язку «Транспорт» [1]. Широкомасштабна модернізація технологічного радіозв'язку пов'язана перш за все з необхідністю зняття з експлуатації всього парку радіозасобів, які не відповідають вимогам діючих державних стандартів. Додатковими обставинами $є$ те, що радіозасоби виробили свій ресурс i не відповідають сучасному рівню розвитку телекомунікаційних технологій.

Подальший розвиток технологічного радіозв'язку буде пов'язаний $з$ впровадженням сучасних цифрових систем i додатковим освоєнням нових діапазонів радіохвиль згідно 3 міжнародними рекомендаціями. Необхідно передбачити організацію дуплексних радіоканалів і можливість передачі великих обсягів даних в системах управління.

В теперішній час розглядають три найбільш перспективні цифрові радіотехнології, які принципово різняться [2 - 4]:

(ㄷ А. О. Єлізаренко, І. О. Єлізаренко, 2018
- радіозасоби цифрового відкритого стандарту мобільного радіозв' язку DMR;

- системи стільникового радіозв'язку GSM-R, на основі найбільш поширеного стандарту цифрового мобільного зв' язку загального користування GSM;

- широкосмугові системи радіозв'язку стандарту LTE.

Процес впровадження нових радіозасобів $\epsilon$ багатогранним i стосується усіх сфер управління рухом поїздів. У зв'язку 3 цим актуальним $\epsilon$ дослідження можливостей використання радіозасобів різних технологій.

\section{Постановка проблеми}

Порівняльний аналіз техніко-експлуатаційних характеристик радіозасобів різних технологій та особливості їх застосування на мережах технологічного радіозв'язку залізниць.

\section{Основні результати}

Радіотехнології розглядають як сукупність методів формування, передачі, прийому радіосигналів, які складають єдиний технологічний процес роботи радіозасобів.

У 2005 році Свропейським інститутом телекомунікаційних стандартів (ETSI) був розроблений стандарт DMR (Digital Mobile Radio цифрове мобільне радіо), як єдиний відкритий загальноєвропейський стандарт цифрового мобільного радіозв'язку [2]. Він забезпечує задачі «цифровізації» систем конвенціонального радіозв'язку i дозволяє модернізувати вже існуючі аналогові мережі шляхом поступової заміни аналогового обладнання на цифрове 
без порушення діючих систем технологічного радіозв'язку 3 частковим використанням існуючої інфраструктури.

Радіозасоби стандарту DMR розраховані на роботу в стандартних смугах частот рухомого радіозв'язку, в тому числі на частотах 146-174 МГц. Для мереж аналогового залізничного технологічного радіозв'язку виділені смуги частот 151,725-156,000 МГц. Саме ці смуги частот передбачається використовувати для цифрових мереж технологічного радіозв'язку стандарту DMR, без виділення додаткових частот. Технологія стандарту DMR побудована на частотному розподілі каналів 3 розносом 12,5 кГц. Використання часового поділу каналів дозволяє створити два незалежних канали на одній несучій для передачі голосу і даних.

Цифрові мережі технологічного радіозв'язку в стандарті DMR можуть працювати в режимі двочастотного симплексу або дуплексу. При цьому рознос частот прийому і передачі повинен бути більше 1 МГц.

В основу роботи цифрових радіостанцій покладено принцип передачі цифрових пакетів. Загальна функціональна схема радіостанції подана на рис. 1.

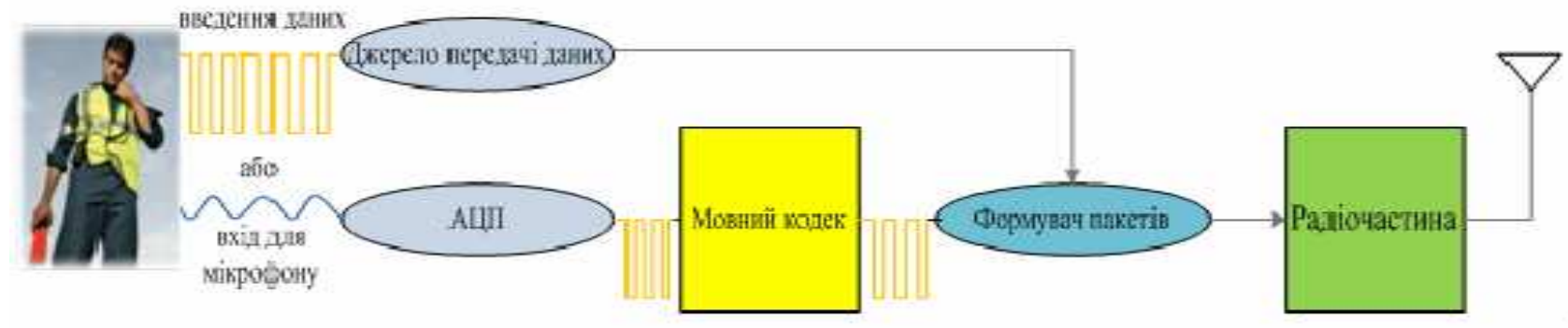

Рис. 1. Функціональна схема цифрової радіостанції DMR

Від абонента (джерела інформації) може надходити два види сигналів - дані або мова. Через мікрофонний вхід звук надходить в звичайний аналого-цифровий перетворювач. На його виході формується цифровий потік зі швидкістю передачі 128 кбіт/с. Цифровий потік 3 такою швидкістю передавати по радіоканалу 3 шириною 12,5 кГц неможливо. Тому для передачі мовної інформації в радіоканалі використовується кодування сигналу. В кодеку звуки порівнюються 3 тими, що зберігаються у власній пам'яті, та за таблицею відповідності кожному присвоюється певний номер. Далі сигнал зі швидкістю 3,6 кбіт/с подається в пристрій формування пакетів, i далі на радіопередавач.

При передачі цифрових сигналів дані безпосередньо надходять в блок формування пакетів і далі - в радіопередавач. Загальна швидкість цифрового потоку в радіоканалі складає 9,6 кбіт/с.

Впровадження радіозасобів стандарту DMR на мережах технологічного радіозв'язку залізниць забезпечує:

- використання існуючої сітки частот, що дозволяє спростити завдання перехідного періоду і забезпечити перехід на рознос частот сусідніх каналів 12,5 кГц;

- ідентичність параметрів радіостанцій за основними характеристиками радіоінтерфейсу дозволяє зберегти умови дальності зв'язку та ЕMC;

- збереження сформованих алгоритмів роботи мереж і прийнятої сигналізації;

- можливість одночасної передачі голосу і даних за рахунок використання часового поділу каналів.
Перехід на сітку частот 3 розносом каналів 12,5 кГц дозволяє збільшити кількість робочих каналів у тій же смузі частот в порівнянні 3 діючими аналоговими системами радіозв'язку. Це дозволить в подальшому більш широко використовувати радіоканали метрового діапазону у відведених для залізничного транспорту смугах частот $151,725-154,000$ МГц і 155,000-156,000 МГц для організації мереж станційного радіозв'язку, зонних мереж поїзного радіозв'язку, окремих мереж ремонтно-оперативного зв'язку та мереж передачі даних для систем управління.

Важливим завданням $є$ розробка нового частотного плану мереж технологічного радіозв'язку в смугах частот 160 МГц, в якому необхідно визначити загальні принципи розподілу частотного ресурсу між різними службами, підрозділами і видами радіозв'язку, передбачити можливість роботи окремих мереж в режимі двочастотного симплексу або дуплексу.

На Південно-Західній залізниці створюється ділянка цифрової мережі DMR на станціях КиївДніпровський, Київ-Петрівка і Борщагівка. Тому зараз на часі розробка концепції і програми впровадження цифрових систем технологічного радіозв'язку стандарту DMR, яка включає пропозиції щодо способів побудови таких мереж в залежності від поставлених задач.

Залізничні адміністрації країн Свропи в 1997 році зробили вибір перспективної технології радіозв'язку на користь стандарту GSM-R (GSM for Railway), створеного на основі найбільш випробуваного i 
І Н Ф О Р М А Ц Й Н О - КЕ Р У Ю Ч І С И С ТЕ МИ Н А З А Л І З Н ИЧ Н О М У Т Р А Н С П О Р Т І

поширеного у світі стандарту стільникового мобільного зв'язку GSM. Україна теж приєдналась до рішення про впровадження систем GSM-R на залізничному транспорті і в найближчій перспективі постане питання організації i проектування таких радіомереж.

Стандарт GSM-R адаптований для залізничного транспорту. Призначений для передачі мови і даних, в тому числі відповідальних команд для інформаційнокеруючих систем. Гарантована швидкість передачі інформації досягає 9,6 кбіт/с. Однак розвиток цього стандарту зупинився на рівні 2008 року. Зараз вже не проводяться роботи 3 його модернізації i удосконалення.

Для мереж GSM-R на залізницях передбачається використання смуг частот для каналів вгору 876-880 МГц і 921-925 МГц (для ліній вниз). 3 точки зору реалізації апаратної частини, система GSM-R потребує мінімального доопрацювання і розрахована на роботу в спільній смузі частот 900 МГц, що забезпечить експлуатаційну сумісність транс'європейської мережі залізничного радіозв'язку. Програмними засобами реалізуються специфічні вимоги залізниць щодо функціональної адресації абонентів, групового виклику, запровадження системи пріоритетів, термінового виклику та ін.

Зараз в більшості країн Європи системи GSM-R знаходяться в стадії впровадження, що дозволить суттєво розширити функціональні можливості радіомереж, підвищити надійність та якість зв'язку.

Різні аспекти впровадження мереж GSM-R на залізницях досить широко розглянуті в науково технічній літературі і розроблені міжнародні рекомендації з їх впровадження [3].

При впровадженні мереж GSM-R необхідно враховувати специфіку умов організації мереж поїзного радіозв'язку на залізницях України. Відповідно до правил технічної експлуатації на всіх ділянках залізниць організуються мережі технологічного радіозв'язку в гектометровому та метровому діапазонах. На ділянках зі швидкісним рухом пасажирських поїздів можлива додаткова організація стільникових мереж стандарту GSM-R або LTE-R.

В умовах суміщеного руху поїздів різних категорій зберігаються існуючі аналогові системи відповідно до вимог ПТЕ i додатково впроваджується цифрова система, наприклад GSM-R, методом накладеної мережі [4]. На рис. 2 наведена схема організації комплексу мереж поїзного радіозв'язку на ділянці залізниці зі швидкісним рухом пасажирських поїздів. Мережі працюють в трьох діапазонах радіохвиль: допоміжна лінійна аналогова мережа гектометрового діапазону, зонні мережі метрового діапазону на частоті 160 МГц і цифрова мережа GSM-R. Робота радіомереж в двох частотних діапазонах УКХ дозволяє забезпечити резервування каналів i підвищити надійність зв'язку, особливо при використанні радіоканалів у системах інтервального регулювання руху поїздів. При використанні одиночного каналу радіозв'язку важко забезпечити коефіцієнт готовності більше 0,9 .

Цифрові системи DMR i GSM-R не повною мірою задовольняють зростаючі вимоги до обсягів i швидкостей передачі інформації в перспективних автоматизованих системах керування рухом поїздів, що пов' язано з вузькосмуговістю стандартів.

Стандарт радіозв'язку, здатний найбільш повно відповідати новим зростаючим вимогам щодо швидкості передач, повинен бути широкосмуговим i підтримувати нові додатки. Як перспективний напрямок розглядається технологія LTE (Long-Term Evolution), як основа для універсальної системи широкосмугового зв'язку. Цей стандарт запропоновано в 2008 році. В теперішній час у світі $є$ декілька комерційних проектів технологічних мереж LTE для залізничного транспорту. Перший з них реалізовано на залізницях Китаю в 2013 році фірмою Huawei. На цій дільниці в мережах технологічного радіозв'язку стали доступні i широкосмугові послуги: відеоспостереження в реальному часі, автоматичне керування локомотивами, визначення місцезнаходження об' єктів.

Стандартом LTE передбачається можливість реалізації системи в діапазонах від 400 МГц до 6 ГГц. Однак можливості вибору частотного діапазону суттєво обмежені. В ряді випадків частотний ресурс уже зайнятий системами радіозв'язку іншого призначення. Для систем LTE в Україні передбачається використовувати смуги частот 1800 МГц і 2600 МГц.

Ширина радіоканалу в системах LTE може бути різною, від 1,4 до 20 МГц. В залежності від використовуваної ширини смуги частот швидкість передачі даних від базової станції до рухомого абонента може складати 7,8 Мбіт/с при ширині смуги 1,4 МГц та може досягати 150 Мбіт/с при максимальній ширині смуги частот та невеликій дальності радіозв'язку з затримкою передачі даних до 5-10 мс. При передачі від базової станції для забезпечення множинного доступу в системі використовується технологія OFDM (Orthogonal frequency-division multiplexing - мультиплексування 3 ортогональним частотним розподілом каналів). Технологія ОFDM передбачає передачу широкосмугового сигналу за допомогою незалежної модуляції вузькосмугових піднесучих, розташованих 3 певним кроком за частотою. У висхідному каналі використовують технологію SC-FDMA (Single-carrier frequency-division multiple access). В мережі стандарту використовується технологія багатоантенних систем (MIMO) $[5,6]$. 


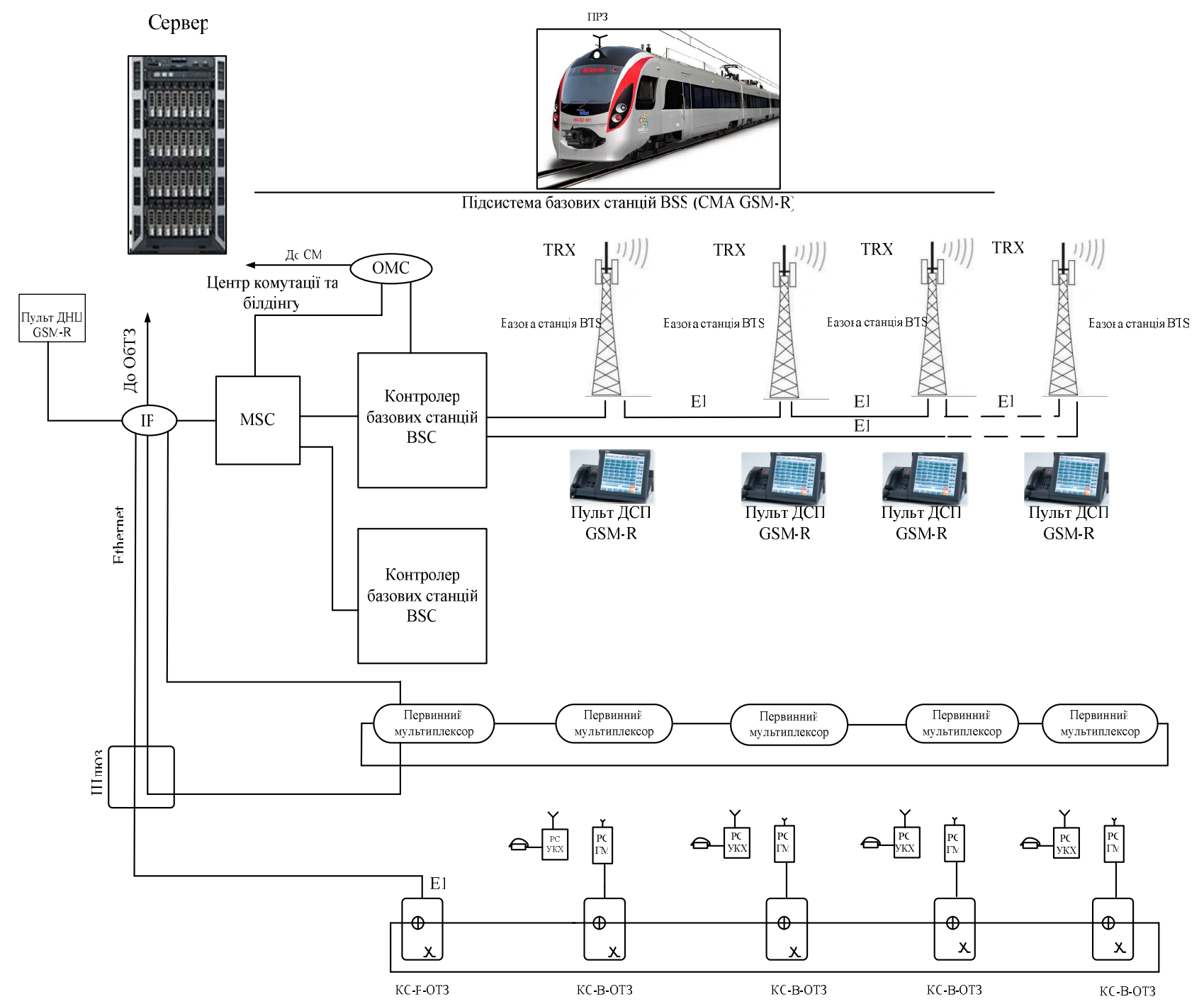

Рис. 2. Схема організації комплексу мереж поїзного радіозв`язку

Міжнародний союз залізниць UIC, Європейська залізнична агенція ERA та Європейський інститут стандартизації в галузі телекомунікацій ETSI беруть участь в розробці єдиного міжнародного стандарту LTE-R для залізничного транспорту та підготовці відповідних специфікацій.

При порівнянні різних радіотехнологій важливим параметром $€$ можливі розміри зон обслуговування, які визначають вартість інфраструктури мережі.

Для розрахунків скористаємось уніфікованою методикою, яка запропонована в роботах $[7,8]$. При розрахунках дальності радіозв'язку використовуємо однакові параметри радіомереж, які не залежать від особливостей радіозасобів різних стандартів.

Визначальним фактором забезпечення необхідної якості радіозв'язку $\epsilon$ характеристика втрат при поширенні сигналів на трасах.
Реальне значення згасання сигналів $L_{\text {мережі }}$ в конкретних умовах організації радіомереж визначають за формулою

$$
L_{\text {мережі }}=L_{\text {осн }}\left(f, h_{1}, h_{2}\right)+B_{\text {трас }}+B_{\text {імов }}, \text { дБ, }
$$

де $L_{\text {осн }}$ - основні втрати на трасах поширення радіохвиль, які визначають за формулою, отриманою для певних умов організації радіомереж;

$B_{\text {mрас }}$ - додаткові втрати, які залежать від конкретних особливостей траси поширення радіохвиль у різних умовах організації радіозв'язку;

$B_{\text {імов }}-$ додаткові втрати, що враховують просторові і часові флуктуації напруженості поля 
сигналів, які визначають виходячи 3 необхідної надійності зв'язку по полю.

Основні втрати в каналах радіозв'язку на залізничних станціях неелектрифікованих ділянок розраховуються за модифікованою формулою Окамури - Хата, параметри якої визначено за результатами експериментальних досліджень, проведених в УкрдУЗТ [9]

$$
\begin{aligned}
& L_{\text {оснст }}=52,35+27,22 \cdot \lg f-13,82 \cdot \lg \left(h_{1}\right)- \\
& \left.-(1,1 \cdot \lg (f)-0,7) \cdot h_{2}+\left(44,9-6,55 \cdot \lg h_{1}\right) \cdot \lg R^{1.15}-2 \cdot\left(\lg \frac{f}{28}\right)\right)^{2},
\end{aligned}
$$

де $h_{1}$ - висота установлення антени стаціонарної радіостанції, м;

$f$ - робоча частота радіомережі, МГц;

$h_{2}$ - висота установлення антени мобільної радіостанції, м;

$R$ - відстань від передавача до точки оцінювання втрат, км.

Максимально допустимий рівень втрат $L_{\partial о n}$, дБ, на трасі поширення радіохвиль, при якому забезпечується необхідна якість і надійність каналів радіозв'язку на межі зони обслуговування

$L_{\partial o n}=P_{n p \partial}-P_{n p м}+B_{n a p}$, дБ,

де $P_{n p д}-$ потужність передавача, дБм;

$P_{n p м}$ - мінімально допустима потужність сигналу на вході приймача, дБм;

$B_{\text {парам }}$ - сума поправкових коефіцієнтів, що залежать від параметрів антенно-фідерних пристроїв передавача й приймача.

Дальність зв'язку залежить від параметрів сигналу, способів його формування і обробки, що визначаються стандартом (методу модуляції, алгоритму мовного кодування, способів завадостійкого кодування та ін.). Ефективність встановлюваних стандартом методів інтегрально відображається в характеристиках чутливості приймального тракту радіостанцій.

Для спрощення розрахунків в умовах невизначеності типів і виробників радіотехнічних засобів мінімальний рівень корисного сигналу приймаємо з урахуванням рекомендацій [3] для систем GSM-R $\quad P_{n р м}=-99 \partial Б м$.
Розрахунки виконані для умов залізничних станцій неелектрифікованих ділянок залізниць для робочих частот 160, 900 i 1800 МГц при висоті антен $h_{1}=20 \mu ; h_{2}=5 \mu ;$ Потужність передавача прийнята $P_{n p \partial}=40$ дБм $\quad\left(P_{n p \partial}=10\right.$ Вт $) . \quad$ Прийнята $\quad$ сумарна поправка $B_{m p a c}=10$ дБ враховує вплив пристроїв електрифікації i корпуса локомотива на умови прийому в локомотивній антені. Сумарна поправка, яка враховує надійність радіозв'язку по полю $B_{\text {мов }}=9,8$ дБ, прийнята 3 урахуванням інтерференційних і часових флуктуацій однаковою для всіх трьох випадків. Загальні втрати в антеннофідерних пристроях прийняті $\quad B_{\text {парам }}=1,5$ дБ. Поправка прийнята виходячи 3 наявного досвіду проектування радіомереж [7, 10]

Дальність радіозв'язку, за умови $L_{\text {мережі }}=L_{\text {доn }}$, можна визначити шляхом безпосереднього розрахунку в ітераційному циклі або подати у вигляді графічного рішення, де дальність зв'язку визначається за точкою перетину кривих $L_{m p a c}$ i $L_{\partial o n}$.

Розрахунки загасання для різних радіотехнологій на робочих частотах радіомереж 160, 900, 1800 МГц наведені на рис. 3.

Дальність складає для радіозасобів стандарту DMR - 12 км, для систем стільникового радіозв'язку GSM-R - 6 км та для широкосмугових систем LTE-R - 4 км.

Використання широкосмугових систем істотно збільшує витрати на організацію мереж за рахунок зниження дальності радіозв'язку. Тому при виборі систем радіозв'язку необхідно орієнтуватись на економічно виправдані витрати на розміщення базових станцій, які визначаються розмірами зон обслуговування. 


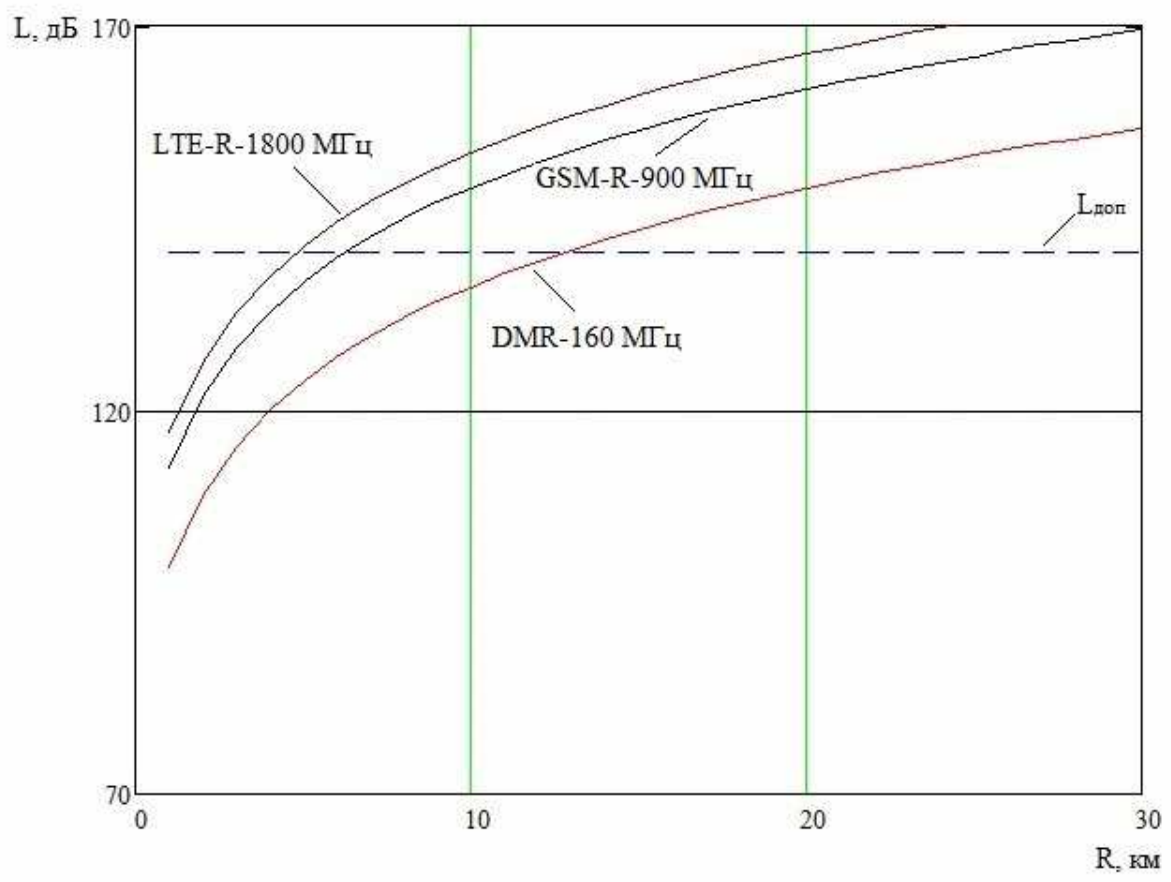

Рис. 3. Результати розрахунку дальності радіозв'язку

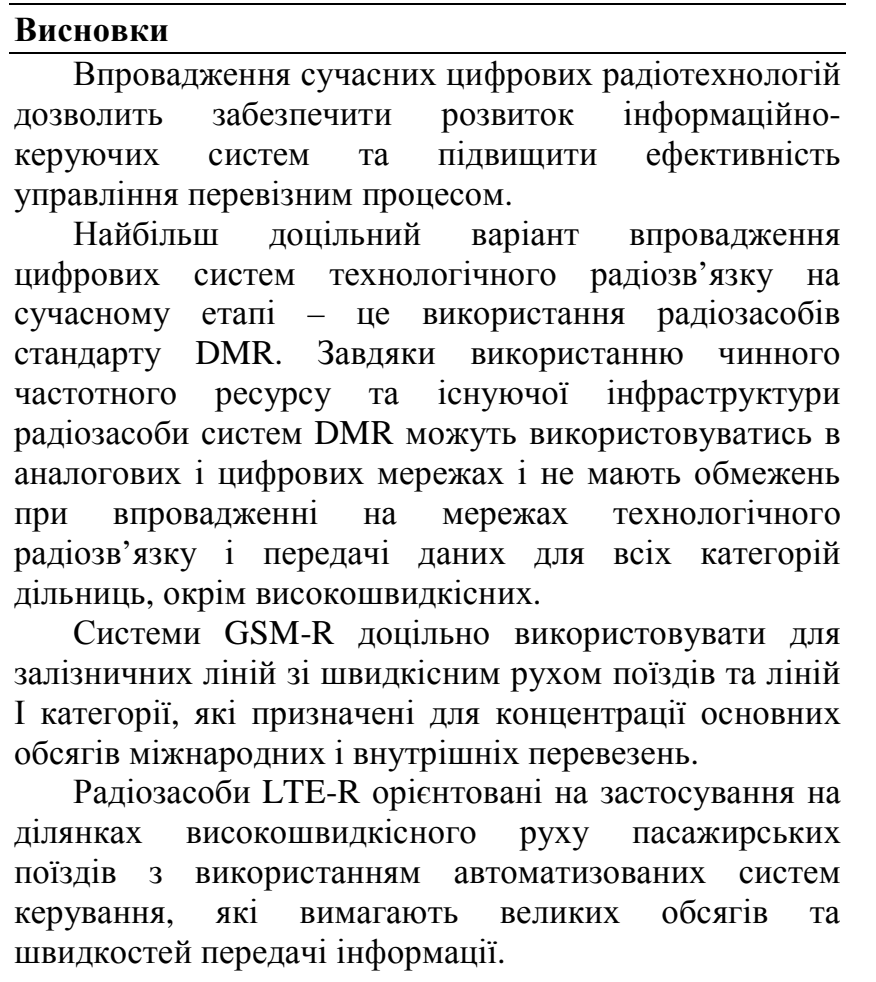

Список використаних джерел

1. Радиотехнические системы железнодорожного транспорта [Текст]: учебник для вузов ж.-д. трансп. / Ю. В. Ваванов, А. В. Елизаренко,
А. А.Танцюра [и др.]. - М.: Транспорт, 1991. $303 \mathrm{c}$.

2. Standard ETSI 102361-1 v1.4.5. Elektromagnetik compatibility and Radio spectrum Matters. Digital Mobile Radio (DMR) Systems. Part1. DMR AIR Interfase hrotocol - France. ETSI, 2007.

3. GSM-R. Procurement \& Implementation Guide [Text] / International Union of Railways-Paris, 2009. - 246 p.

4. Правила експлуатації поїзного радіозв'язку [Текст]: затв. наказом Державної адміністрації залізничного транспорту України від 24.09.2007 p № 452-Ц. - К., 45 c.

5. ITU-R IMT-Advanced $4 \mathrm{G}$ standards to usher new era of mobile broadband communications // International Telecommunication Union, 2010. - URL: http://www.itu.int/net/hressoffice/press.

6. Тихвинский, В. О. Сети мобильной связи LTE: технологии и архитектура [Текст] / В. О. Тихвинский, С. В. Терентьев, А. Б. Юрчук. М. : Эко-Трендз, 2010. - 284 с.

7. Слізаренко, А. О. Розробка методології розрахунку дальності дії каналів рухомого радіозв'язку в умовах впливу інфраструктури залізниць [Текст] / А. О. Слізаренко // Інформаційно-керуючі системи на залізничному транспорті. - 2014. - №2. C. 61-65.

8. Горобец, Н. Н. Особенности расчета энергетических характеристик каналов подвижной радиосвязи [Текст] / Н.Н. Горобец, А. А. Елизаренко // Радиотехника: Всеукраинский 
межведомственный науч.-техн. сб. - Харьков: ХНУРЭ, 2017. - Вып. 188. - С. 116-125.

9. Слізаренко, А. О. Удосконалена статистична модель для розрахунку енергетичних характеристик каналів залізничного технологічного радіозв'язку [Текст] / А. О. Єлізаренко // Інформаційно-керуючі системи на залізничному транспорті. - 2015. - №2. C. $37-42$.

10. Пилипенко, А. М. Проектирование беспроводной городской сети связи четвертого поколения [Электронный ресурс] / А. М. Пилипенко, С. А. Ефремов // Современные научные исследования и инновации. - 2015. - № 12. Режим

http://web.snauka/issues/2015/12/61436.

Елизаренко А. А., Елизаренко И. А. Особенности внедрения современных цифровых радиотехнологий на сетях связи железнодорожного транспорта. Проведен сравнительный анализ цифровых радиотехнологий DMR, GSM-R и LTE-R. Рассмотрены принципы построения и основные технико - эксплуатационные характеристики радиосредств и направления использования для технологических абонентов различных категорий. Разработаны рекомендации по внедрению радиосредств различных технологий на сетях подвижной радиосвязи железных дорог.

Наиболее целесообразный вариант внедрения цифровых систем технологической радиосвязи на современном этапе - это использование радиосредств стандарта DMR. Он обеспечивает задачи «цифровизации» систем конвенциональной радиосвязи и позволяет модернизировать уже существующие аналоговые сети путем постепенной замены аналогового оборудования на цифровое, без нарушения действующих систем технологической радиосвязи с частичным использованием существующей инфраструктуры. Системы GSM-R целесообразно использовать для железнодорожных линий со скоростным движением поездов. Радиосредства LTE-R ориентированы на применение на участках высокоскоростного движения пассажирских поездов с использованием автоматизированных систем управления, что требует больших объемов и скоростей передачи информации.

Проведенные расчеты показали уменьшение дальности радиосвязи в сетях GSM-R и LTE-R, что приводит к росту стоимости инфраструктуры сетей. Ключевые слова: железнодорожная технологическая радиосвязь, цифровые радиотехнологии DMR, GSM-R и LTE-R, принципы построения, рекомендации по применению, расчет зон обслуживания радиосетей.
Yelizarenko Andriy, Yelizarenko Ihor. Features of the introduction of modern digital radio technologies on railway communication networks. A comparative analysis of digital radio technologies DMR, GSM-R and LTE-R was carried out. The principles of construction and basic technical and operational characteristics of radio equipment and directions of use for technological subscribers of different categories are considered. Recommendations on the introduction of radio equipment of various technologies on networks of mobile radio communications of railways are developed.

The most expedient way of introducing digital systems of technological radio communication at the present stage is the use of radio equipment of the standard DMR. It provides the task of "digitization" of conventional radio communication systems and allows modernization of existing analogue networks by gradual replacement of analogue equipment on a digital basis, without violating existing systems of technological radio communication with the partial use of existing infrastructure. GSM-R systems should be used for high-speed train trains. Radio equipment LTE-R is targeted at applications in high-speed trains of passenger trains using automated control systems that require large volumes and speeds of information transmission.

The conducted calculations showed a decrease in the radio communication in networks GSM-R and LTE-R, which leads to an increase in the cost of network infrastructure.

Keywords: railway technological radio communication, digital radio technology DMR, GSM-R and LTE-R, principles of construction, recommendations for application, calculation of radio network service areas.

Надійшла 07.12.2017 p.

Yelizarenko Andriy, docent of "Transport connection" department, Candidate of Techn. Sciences, PhD, Ukrainian State University of Railway Transport, Kharkiv, Ukraine. E-mail: elizarenkol@ukr.net ORCID: https://orcid.org/0000-0002-8567-7576

Yelizarenko Ihor, State Enterprise "Ukrainian State Centre of Radio Frequencies", engineer of 1 category. E-mail: elizarenkol@ukr.net

Слізаренко А.О., к.т.н., доцент кафедри транспортного зв'язку, Украӥнський державний університет залізничного транспорту, Харків, Україна. E-mail: elizarenkol@ukr.net ORCID: https://orcid.org/0000-0002-8567-7576

Слізаренко І. О., провідний інженер Харківської філіі Украӥнського державного центру радіочастот. E-mail: elizarenko1@ukr.net 